\title{
Correction to: A feminist ethos for caring knowledge production in transdisciplinary sustainability science
}

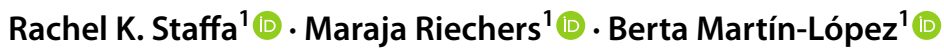

Published online: 6 January 2022

(c) The Author(s) 2022

\section{Correction to: Sustainability Science https://doi.org/10.1007/s11625-021-01064-0}

In the original publication of the article, the section "Situated knowledges" is not the part of Introduction section. It should be included under "Box 1 Key terms and definitions" and it has been corrected in the original article.

Under the section "Cultivating caring academic cultures", the reference "Kosanic et al. 2019" should be replaced with "Tuosto et al. 2020" and the correct sentence should read as follows, "Even less is discussed when the researcher is the one disabled (but see Hartman 2019; Tuosto et al. 2020; and see Box 2 for a discussion on how a feminist ethos of care can contribute to support scholars with disabilities in Transdisciplinary Sustainability Science)."

In addition, the respective reference should read as below,

Tuosto K, Johnston JT, Connolly C, Lo C, Sanganyado E, Winter KA, Roembke T, Richter WE, Isaacson KJ, Raitor M, Kosanic A, Bessone L, Heim AB, Srivastava P, Hughes PW, Aamodt CM (2020) Making science accessible. Science 367(6473):34-35. https://doi.org/10.1126/science.aba6129

Further, there are few spelling errors in the following sentence "This puts even more strain on the well-being of scientists ..." under the "Box 2 Considering disability in Transdisciplinary Sustainability Science through a feminist ethos of care". The correct sentence should read as follows,

The original article can be found online at https://doi.org/10.1007/ s11625-021-01064-0.

Rachel K. Staffa

rachelstaffa@yahoo.de

Maraja Riechers

riechers@leuphana.de

Berta Martín-López

martinlo@leuphana.de

1 Social-Ecological Systems Institute, Faculty of Sustainability, Leuphana University Lüneburg,

Universitätsallee 1, 21335 Lüneburg, Germany
"This puts even more strain on the well-being of scientists with disabilities as they are placed in a treadmill-wheel, a non-winnable and non-equal academic race."

Finally, the first paragraph of acknowledgments was published incorrectly. The correct acknowledgment should read as follows, "We gratefully acknowledge the insightful comments by two reviewers, as well as Aleksandra Kosanic's work on disabilities and global environmental change and her comments throughout the main text that have inspired us to expand further on this minority group."

The original article was updated.

Open Access This article is licensed under a Creative Commons Attribution 4.0 International License, which permits use, sharing, adaptation, distribution and reproduction in any medium or format, as long as you give appropriate credit to the original author(s) and the source, provide a link to the Creative Commons licence, and indicate if changes were made. The images or other third party material in this article are included in the article's Creative Commons licence, unless indicated otherwise in a credit line to the material. If material is not included in the article's Creative Commons licence and your intended use is not permitted by statutory regulation or exceeds the permitted use, you will need to obtain permission directly from the copyright holder. To view a copy of this licence, visit http://creativecommons.org/licenses/by/4.0/.

Publisher's Note Springer Nature remains neutral with regard to jurisdictional claims in published maps and institutional affiliations. 